\title{
DIE BEOEFENING VAN DIE KERKREG IN DIE GEREFORMEERDE KERK IN S.A. SEDERT 1859
}

\section{Inleidend}

Die onderwerp sal vanuit twee hoeke benader word.

1.1. In die eerste lesing sal gepoog word om 'n terugblik te gee op die beoefening en die toepassing van die kerkreg in die Gereformeerde Kerk in S.A., om sodoende aan te toon hoedat kerkregtelike insigte en die toepassing daarvan in die praktyk van deurslaggewende betekenis was vir die ontstaan en ontwikkeling van die Gereformeerde Kerk in S.A.

1.2. Tweedens word 'n toekomsblik gewerp om aan te toon hoedat die beoefening van die kerkreg en daarmee die kerkregering, ook van deurslaggewende betekenis vir die toekoms van die Gereformeerde kerk in S.A. is. Die vraag na die verhouding van die kerkreg en kerkregering tot die wese van die kerk dien as uitgangspunt vir die tweede lesing oor Die Kerkreg en die wese van die kerk.

\section{Verantwoording oor die aktualiteit}

2.1. Ten opsigte van die eerste voordrag is die vraag na die kerkreg veral aktueel as ons dit sien teen die agtergrond van beweringe soos die van B. J. Odendaal $(1957$; p. 146) ook op gesag van S. P. Engelbrecht (1953; p. 141), e.a. dat die stigting van die Gereformeerde Kerk in S.A. maar één oorsaak gehad het en dit was die gebruik van die evangeliese gesange in die openbare erediens. Verder sou ds. D. Postma volgens Odendaal hoofsaaklik uitgestuur gewees het as sendeling onder die heidene. (p.p. 146 e.v.). Hy het ook geen opdrag tot kerkstigting gehad nie (p. 157) maar misbruik gemaak van 'n nood aan predikante ,om 'n eie wending aan die kerklike lewe in Transvaal te gee' en 'n nuwe kerk gestig (p. 160). P. B. van der Watt (1977) gee die algemene opvatting van kerkhistorici uit Ned. Geref. sowel as Hervormde kringe weer, as hy skryf dat die ,afskeiding" nie die toets kon deurstaan van die gereformeerde kerkregtelike beginsels nie (p. 85). Die uitsprake is al dikwels weerlê en die herhaling daarvan sou net 'n verwysing na die weerlegging in die verlede verdien het, as dit nie was dat daar tekens is dat daar deesdae in ons eie geledere, veral onder die jonger geslag twyfel bestaan oor die reg van die Gereformeerde Kerk in S.A. teenoor die ander in die lig van die Skrif nie.

2.2 . Vir die tweede voordrag vind mens aanleiding in 'n stelling soos die van M. R. van den Berg (1969): ,de bestaande kerkelijke organisatie is niet alleen voor de Zoeloes (hy was sendeling in Natal. G. P. L.) een verwerpelijke zaak, maar betekent ook voor de westerse kerken zelf een belemmering voor het waarachtig kerk zijn ...." (p. 11). Die bestaande kerklike organisasie het die kerk aan bande gelê en het „steriliserend op het leven van de kerk ingewerk" (p. 13). Hy wil terug na die Skrif en dan veral kyk wat die N.T. sê oor die inrigting van die kerk van Christus (p. 13). Dit gaan 
daarby egter vir hom nie om die vraag of die bestaande organisasie ooreenkomstig die D.K.O. Skriftuurlik gefundeer is nie en of dit net verkeerd gebruik word nie, ,hoezeer dat ook te konstateren valt. Het gaat tegen het bestaan van de K.O. als bindend kerkorganisatorisch document als zodanig". (p. 68). Ten oorvloede haal ek Van den Berg nog eens aan: „Een met bindend gezag opgelegde kerklijke organisatie makt de gemeente van Christus tot een gekerkerde kerk" (p. 69).

Hierdie uitsprake dui op die toenemende geringskatting van die amp wat uit die herlewing van die konsensus van die Aufklärung gedurende die einde van die vorige eeu aangaande die amp opkom. Volgens Ulrich Brockhaus (1972) staan die konsensus ook op gesag van Olof Linton (1932), vas dat by die aanvang van ,,aller christlichen Gemeindeorganisation die Autonomie der einzelnen Gemeinde: Die Gemeinden regierten sich democratisch selbst" (p. 7) die uitgangspunt was.

Hierdie selfbeskikking sluit die leiding, ,durch berufsmäszige Organe und insbesondere durch ein leitendes Lehramt aus". (p. 7).

Die apostels, profete en leraars het geen „Gemeindeamt” gehad nie (p. 8). Die gesagsvolle ampsbediening versmoor die kerk. Daarmee is ons ook terug by Rudolph Sohm (1892) se uitspraak: „Das Kirchenrecht steht mit dem wesen der Kirche im Widerspruch". (p. 1).

Kerkreg is dan eintlik 'n onderdeel van die algemene regswetenskap in soverre dit die goeie orde van die kerk as samelewingsverband op die oog het (vgl. Erik Wolf 1961, p. 1). Die kerkreg is dan deels 'n teologiese wetenskap en deels 'n onderdeel van die algemene regswetenskap (Otto Friedrich 1961; p. 15). Die uiterste konsekwensie van die opvatting is dat dit in die kerkreg om niks anders gaan as om te sorg dat alles in die kerk net glad verloop nie. Die amp hr alleen administratiewe betekenis (vgl. Ulrich Brockhaus 1972; p. 8). Dit sou beteken dat die beoefening van die kerkreg 'n betreklik onverskillige saak is. Solank alles in die kerk maar vlot verloop hoef daar geen kommer te wees oor watter kerkreg en hoe dit beoefen word nie.

Hoewel J. Plomp (1967) andersyds meen dat mens die kerkreg nie moet verag nie, maar "men ... zij er ook niet al te benauwd voor" (p. 12), hou bostaande opvatting tog die gevaar van institutionalisme in, waarteen deesdae uit baie oorde gewaarsku word. (Vgl. M. R. v.d. Berg 1967 en B. Spoelstra 1976, pp. 41 en 42 by implikasie, en 1977 p.p. 45 e.v.), nie uit nie. Die regspositivistiese standpunt dat 'n besluit geldig en afdwingbaar is bloot omdat die kerkraad of sinode besluit het, beheers dan sodanige kerkregtelike beskouinge.

In die lig van hierdie opvattinge, wat ook in ons eie kringe vrae laat ontstaan, meen ek dat ons onderwerp vir elke bedienaar van die Woord, wat ook kragtens sy profetiese amp leiding moet gee in die beoefening van die kerkreg, besonder aktueel is.

\section{3. 'n Terugblik op die beoefening van die kerkreg in die Gerefor- meerde kerk in S.A. sedert 1859.}

3.1. Dit is seker 'n ambisieuse onderneming om ' $n$ indringende oor- 
deel te vel oor die beoefening van die kerkreg wat oor meer as 'n eeu strek. Aanvanklik lyk dit asof die taak spoedig afgehandel kan wees as net op die doelbewuste beoefening van die kerkreg as wetenskap toegespits word. Veral wat die eerste halfeeu van die bestaan van die Gereformeerde Kerk in S.A. betref, lyk die oes maar skraal in die opsig.

Sonder om aanspraak te maak op volledigheid kan beweer word dat die resultate van doelbewuste wetenskaplike aandag wat aan die kerkreg bestee is, opgesom is in enkele publikasies. Gedurende 1921 het die doktorale proefskrif van dr. C. J. H. de Wet, „Die Kollegiale Kerkreg" (V.U. Amsterdam) verskyn. Kort daarna, 1923, laat dr. P. J. S. de Klerk ewe-eens sy proefskrif, Kerk en Sending in S.A., (V.U., Amsterdam) die lig sien. Die volgende proefskrif verskyn eers twintig jaar later as dr. J. P. Jooste in 1946 skryf oor ,Die verhouding tussen Kerk en Staat aan die Kaap tot die helfte van die negentiende eeu" (Univ. S.A.). Weer twintig jaar later promoveer dr. G. P. L. van der Linde met 'n proefskrif: "Die Grondbeginsels van die Presbiteriale kerkregeringstelsel" (P.U. vir C.H.O. 1965) en dr. J. J. van der Walt met „Christus as Hoof van die Kerk en die Presbiteriale Kerkregeringstelsel" (P.U. vir C.H.O. 1976). Benewens die proefskrifte moet nog enkele Meesters en doktorale skripsies, wat nie gepubliseer is nie, vermeld word.

Verder is daar ook die Kerkreg Diktate van Proff. J. D. du Toit, J. P. Jooste en G. C. P. v.d. Vyver. Van die hand van prof. J. D. du Toit het nog verskyn in 1906, Die Amp van die Ouderlinge en Diakens terwyl talle artikels oor kerkregtelike sake deur die jare heen in Die Kerkblad opgeneem is. (Gebundel in D1. VI: Versamelde Werke van J. D. du Toit, 1961 vanaf bls. 391). Gedurende 1925 het prof. J. A. du Plessis ook die polemiese geskrif, Die Gereformeerde Kerk en Kerkregering (Nas. Pers Boekhandel) teen sy naamgenoot uit Stellenbosch, laat verskyn. "Die Handleiding by die Kerkorde" van Kruger, du Plessis en Spoelstra, vader en seun, was 'n antwoord op die verlange na 'n verklaring van die kerkorde.

Sedert die jare vyftig het kerkregtelike artikels in ,Die Kerkblad" o.a. van die van prof. S. du Toit, 'n prominente plek ingeneem. Brosjures soos die van prof. J. P. Jooste oor „Die Roeping tot die Amp van die predikant", die van dr. B. Spoelstra en andere oor die diakonale amp, het die kerkregtelike literatuur verryk. Ook in verskillende versamelwerke soos die populêre „Handleiding vir Ouderlige" 1949; die wetenskaplike „Die Koninkryk van God", 1969, en die Teologiese tydskrif, In die Skriflig, lewer waardevolle artikels met die oog op die beoefening van die kerkreg in die Gereformeerde Kerk in S.A. Die verskillende gedenkuitgawes vanaf 1909, sedert die halfeeufeesvieringe tot met die Eeufeesviering in 1959, bied 'n verdere rykdom van stof. Vir 'n opgawe van Skriftelike Getuienis uit die Gereformeerde Kerk, (waaronder werke en artikels van kerkregtelike aard) deur prof. dr. J. Chr. Coetzee, word u verwys na „Die Gereformeerde Kerk in S.A. 1859 - 1959", p. 138 e.v.

Om net op grond van hierdie bronne, of selfs in die eerste plek op grond daarvan, 'n oordeel te probeer vorm oor die kerkregtelike stand in die Gereformeerde Kerk in S.A., sal simplisties wees. Die 
werke gee maar ' $n$ deel van die beeld weer. Om te weet wat op kerkregtelike gebied in die kerk leef moet ons allereers die worstelinge rondom die ontstaan daarvan ontleed om daarna te let op die verdere ontwikkeling.

\subsection{DIE WORDINGSPERIODE}

3.2.1. Wat aan die stigting van die Gereformeerde Kerk in S.A. voorafgegaan het.

Die geskiedenis is veral deur dr. B. R. Kruger (1957), prof. J. P. Jooste (1958), dr. G. C. P. v.d. Vyver (1958) en dr. B. Spoelstra (1963) indringend beskryf. Die skrywers het ook 'n duidelike beeld van die hele gesangekwessie gegee. Dit kom daarop neer dat die gesange, waarin die teologiese beskouinge van die Aufklärung sterk na vore kom, gedurende 1814 ingevoer is sonder dat 'n meerdere vergadering ooit daaroor gespreek het (vgl. v.d. Vyver 1958, p. 202).

Sommige lidmate veral te Cradock, Colesberg en Burgersdorp het besware ingebring teen die regsinnigheid van die gesange. Die Ring van Graaff-Reinet wat op die besware in 1841 moes ingaan noem hulleself in 'n Herderlike brief in 1842, ,Wij die van God gesteld zijn voor uwe zielen te waken ... ", en praat verder van ,Gij, broeders en zusters, die bezwaring gevoeld ..." (Afgedruk by J. Lion Cachet 1909 , p. 12). In die Herderlike brief spreek hulle ook 'n oordeel uit oor die beswaardes as sou hulle deur hulle vooroordeel en styfhoofdig. heid die harte van die liggaam van Christus deurboor en verskeur en stel hulle voor die naderende dag van die Here waarop hulle rekenskap sal moet gee van die ,regt gebruik of misbruik van alle liedere? op Gods Woord gegrond, en daarmede overeenkomstig (waarvoor wij de Evangelische gezangen houden)", (J. Lion Cachet 1909, p.p. 14/5).

$\Lambda \mathrm{l}$ grond vir hierdie verklaring is dat die ,leraars van die Gereformeerde Kerken in Holland en in Zuid-Afrika" nie ,,iets zouden vasthouden als deze gezangen," as hulle gedink het „dat iets tegenstrijdig of niet overeenkomstig met het woord des Heeren en de Geloofsbelijdenis van onze kerk daarin te vinden waren" (J. Lion Cachet, 1909 , p. 14). Die Sinode 1847 onderskryf die bevinding stilswygend deur die goedkeuring van die Herderlike-brief (v.d. Vyver 1958, p. 181), ewe-eens sonder om dit te toets aan Gods Woord (B. R. Kruger, 1957, p.p. 78 e.v.)

'n Beeld verrys dus voor ons van gelowiges wat kla by die „wat van God gesield zijn” om oor hulle ,zielen te waken”, dat die Woord van God vervals en in die vorm van onregsinnige gesange op hulle afgedwing word. In plaas van 'n uitspraak op grond van Gods Woord op hulle klag word die klaers in 'n bestraffing gebrandmerk as deurboorders van die liggaam van Christus, omdat predikante so sê !

Die wordingsperiode van die Gereformeerde Kerk in S.A. word so deur 'n kerkregtelike worsteling beheers waarin die gelowiges die kerk wil laat bly terwyl die geroepe kerkregeerders in roepingsontrou aan hulle self en hulle ordonnansies meer mag en gesag toegeken het as aan die Woord van God (N.G.B. art. XXIX). Dieselfde patroon van die Ring van Graaff-Reinet is deur die kerklike vergaderinge teenoor die beswaarde J. J. Venter in die Oranje Vrystaat gevolg. In die Zuid-Afrikaansche Republiek het die Algemeene Kerk- 
vergadering sedert 1853 die besware van $\mathrm{Ph}$. Snyman, P. Venter, S. J. P. Kruger en andere, opsy geskuif. In 1856 was dit al só ver dat Snyman en andere „De Kerkraad (Hervormde Kerk) en leraar bedankt heeft". Die redes wat hy in sy brief aan Kommandant Generaal M. W. Pretorius verstrek is dat in die kerk nie geleer en geregeer word ooreenkomstig die bepalinge van Dordrecht 1618/19 nie. (Brief by G. C. P. v.d. Vyver 1958, vgl. p.p. 215223). En as die 15 man te Pretoria uit die Algemene Kerkvergadering van Transvaal uitstap op 11 Januarie 1859 , doen hulle dit nadat die Vergadering besluit het „De Kerkelijke inrichting, maar ook niets meer . . . zal in stand blijven" (Geschiedenis sedert 1858 p. 10).

Daarna gee hulle kennis dat hulle wens te bestaan ,als eene vrije Gereformeerde Kerk, overeenkomstig de leer, tucht en dienst der vaderen ..." (Geschiedenis sedert 1858, p. 11). Met hierdie besluit van die Algemene Kerkvergadering en die reaksie daarop is die jare'ange kerkregtelike worsteling - sedert die Ringsitting te Graaff-Reinet 1841 - besleg. Die weë het uiteen gegaan; egter nie vanweë die blote hardkoppige weiering om gesange in die erediens te sing (o.a. Odendaal 1957) nie. Dit het gebeur omdat die broeders aan die grondliggende en allesbeheersende beginsel van die kerkreg vasgehou het naamlik dat Christus sy kerk deur sy Gees en Woord regeer. In sy Journaal skryf ds. D. Postma dat dit vir die broeders „,nu onmogelijk (was) om onder zulk een overheerschend kerkbestuur langer in die kerkelijke Gemeenschap te blijven . ." ook afgedruk by D. Postma 1905 p. 123).

That dus c'e..r sommige historici van mond tot mond deurgegec word as bloot 'n kwessie van die sing of nie sing nie van gesange nie, blyk so te wees die kerkregtelike belewing van die belydenis dat Jesus Christus die Here is; Hoof van sy Kerk en aan Wie alleen gehoorsaamhe d verskuldig is (vgl. G. P. L. v.d. Linde 1959, veral p. 11 e.v.) Van der Vyver (1958) verklaar tereg dat die gesange net die uitwendige en konkrete was wat die kruit uiteindelik laat ontplof het (p. 244). Wanneer Dr. P. B. v.d. Watt (1977) nog steeds volhou dat die „afske 'ding" nie die gereformeerd kerkregtelike toets kon deurstaan nie, getuig van 'n onvermoë of onwil om in hierdie geval die bronne teen die juiste kerkhistoriese agtergrond te interpreteer.

\section{Die kerkregtelike aspek op Sinode Leiden 1857.}

Hierdie beslegting van die stryd in die uiteengaan van die weë neem in betekenis toe as ons daarop let dat die stigting van die Gereformeerde Kerk in S.A. ook die afloop was van 'n kerkregtelike daad wat in Nederland begin is, op die Sinode van Lciden 1857. Die heer J. S. van Andel, graanhandelaar en ouderling le 's Hertogenbosch, afgevaardigde ,uit de Provincie Noord Brabant", het die behoefte aan Woordbeclicn.ng in die Zuid-Afrikaansche Republiek onder die aandag gebring. Die Sinode besluit daarop om aan die ,Synodale Commiss'e op te dragen, zich in correspondentie te begeven met die Gemeenten aldaar, haar inlichtingen te geven en de bereidwilligheid der kerk te openbaren, om zoveel mogelijk in hare behoeften te voorzien" Art. 139, Leiden, afgedruk by D. Postma 1905, p.1). Terloops, 
van sending onder die heidene is hier geen sprake nie, ook nie in die latere lasbrief van ds. Postma nie (p. 45).

Wel was daar altyd die gedagte en hoop dat die hulp aan ,onze stamverwanten en geloofsgenoten aldaar" 'n geopende deur vir die verkondiging van die Woord aan die heidene sou gee (vgl. D. Postma Jnr. 1893 ; p. 15 e.v.).

Die sinodale kommissie het dadelik aan die werk gespring en op 3 Julie 1857 aan die Kaapse teologiese student C. H. de Smidt te Utrecht geskryf om vas te stel hoe hulle te werk moes gaan. Uit 'n vroeëre skrywe van die N.G. Kerk moes dit duidelik gewees het dat hulle afsydig gestaan het teenoor die Afskeiding van 1834 in Nederland. Onder die indruk dat die N.G. Kerk ook seggenskap oor die kerklike sake in Transvaal gehad het, wou hulle nie buite hulle om werk nie. Op advies van De Smidt (vgl. brief by Postma 1905, p. 1) en aangespoor deur Van Andel (Postma 1905, pp. 3-5) besluit die kommissie om in medewerking met die N.G. Kerk van S.A. 'n predikant en 'n ouderling na die Z.A.R. af te vaardig (vgl. Brief aan N.G.K. by Postma 1905, p. 43). Ds. N. H. Dosker en ouderling Van Andel word afgevaardig en as ds. Dosker bedank, val die keuse op ds. Dirk Postma van Zwolle.

Dat hierdie optrede van die kommissie kerkregtelik deeglik verantwoord moes word, is duidelik uit die redes wat ds. Dosker in sy bedanking aangee. Hy was van oordeel dat

1. die Noord-Brabantse Provinsiale Sinode nie die nodige erns aan die saak gegee het nie en het ,zonder bezondere notitie daarvan te nemen" goedkeuring geheg aan die voorstel om die saak na die Sinode te verwys;

2. die sinodale kommissie het buite hulle bevoegdheid gehandel deur hom af te vaardig. Hy meen dat hulle volgens hulle opdrag ten minste eers deur briefwisseling moes vasstel wat die omstandighede in die Z.A.R. was, voordat hulle verder kon op tree;

3. Daar kerkregtelik nie 'n weg was waarvolgens die sending verantwoord kon word nie. Art. 14 D.K.O. nog art. 7 kon van toepassing wees nie. As op art. 7 teruggeval word, vanwaar dan die sending van 'n ouderling?

4. Daar is geen grond om ,welvarende buitelanders" te help „terwijl daar zoo vele gemeenten in ons vaderland door gebrek aan stoffelijke middelen van de Evangelie-prediking verstoken zijn ..." (Postma 1905, pp. 6-8).

Dit kom dus daarop neer dat ds. Dosker sy weg nie oop gesien het om die benoeming te aanvaar nie omdat dit kerkregtelik nie verantwoord was nie.

Hoewel ds. Postma in die benoeming ' $n$ roeping van die Here sien, kan hy nie tot 'n besluit kom nie omdat ,die zaak nog niet duidelijk genoeg" is nie (Brief 29 Dec. 1857, by Postma 1905, p. 11). Op 15 Januarie 1858 skryf ds. Postma dat hy ,geneig is tot de opvolging van de door u op my uitgebragte benoeming naar Transvaal", maar die benoeming ,wordt van sommigen bestreden". Hy sou graag wou ver 1. of die Sinodale kommissie die benoeming kon verdedig teen dié wat sê hulle ,heeft geen macht, om die zending ten uitvoer te leggen, althans niet om een leraar uit zijne gemeente op te nemen;" 
2. hoe die kommissie die sending gaan bekostig daar hulle geen mag het om die kerk te beswaar nie;

3. of dit so is dat, indien hy die benoeming aanvaar, ,ik overgaan van de dienst van eene partikuliere gemeente in die van de geheele kerk, ..." (Postma 1905, p. 12).

Wat die Sinodale kommissie presies geantwoord het vermeld Postma (1905), nog B. R. Kruger (1957) nog v.d. Vyver (1958); ook kan ek nog nie 'n dokument in dier voege vind nie. Van der Vyver verklaar die ,macht om de zending ten uitvoer" te bring uit art. 48 D.K.O. Korrespondensie ooreenkomstig die artikel sluit ook die „persoonlijke korrespondentie" in. Op die Sinode te Hoogeveen 1860, het daar wel 'n vraag gedien of die kommissie die reg gehad het om 'n afvaardiging te stuur, maar daarop is geen ,aanmerking gemaakt" (v.d. Vyver, pp. 166/7). Dit is waarskynlik dat ds. D. Postma, wat self nie getwyfel het ,of gij handelt volgens uwen last" (brief 15 Jan. 1858, by Postma 1905, p. 12), die saak ook in die lig gesien het en dat hy 'n bevredigende antwoord op sy vrae gekry het nie, want op 11 Februarie 1858 antwoord hy ,dat $\mathrm{ik} \mathrm{mij} \mathrm{geroepen} \mathrm{gevoel}$ my bereidvaardig te verklaren" (by Postma 1905, p. 13).

Dit is dus duidelik én uit die weg waarlangs die aandag aan die geestelijke belange van die inwoners van die Z.A.R. én uit die wyse waarop ds. Postma afgevaardig is, dat daar nie sommer lukraak op 'n kerklike avontuur afgestuur is nie. Daar is met verantwoordelikheid geworstel deur alle partye en die kerkregtelike weg was vir hulle deurslaggewend.

Postma en die reg van sy sending teenoor Odendaal, Van der Watt e.a.

Wat ds. Postma verder betref, die roeping van Godsweë staan vir hom voorop. Om hom daaraan te onderwerp het 'n hewige stryd gekos. „Dan eens een hevige strijd met de woorden: zijt uselven genadig! Dan eens de grootste gewilligheid met het oog op: ,Gods Zoon in de beesten krib ...'Dan ja dan drong de liefde (van) Christus mij sterk" (brief 11 Februarie 1858; ook sy afskeidspreek op 11 April te Kampen. Postma jnr. 1893, p. 15). In sy brief aan die Algemeene Vergadering op 11 Januarie 1859 lê hy ook alle nadruk op ,mijne goddelijk zending" (Postma 1905, p. 13).

Sowel die Sinode van Leiden 1857 as ds. Postma self het alleen die bevordering „van Gods Koninkryk aldaar" op die oog gehad. Die kerk, so word hy nie moeg om in sy afskeidspreke voor sy vertrek te beklemtoon nie, is ,de gemeente Gods" (D. Postma 1893, p. 1) en hulle is duur gekoop deur die bloed van Jesus die Middelaar (vgl. pp. 3 en 4). "Gods gemeente", verkondig hy ten afskeid aan die kerk te Zwolle op 21 Maart 1858, word verseker „ziet, Ik ben met $\mathrm{u}$ al de dagen tot aan de voleindiging der wereld. Matth. 28:20".

Die aanhalings bewys dat die wat gestuur het en hý wat gestuur is, alleen gehandel het onder die besef dat die kerk die duurgekoopte eiendom van God in Jesus Christus, die Hoof van die kerk is. Die bewyse kan vermenigvuldig word uit amptelike stukke wat betrekking het op die sending.

In die lig van wat in Suid-Afrika sowel as in Nederland aan die stigting van die Gereformeerde Kerk in S.A. voorafgegaan het, is 
die krasse oordeel van Odendaal (1957) dat Postma sy sendingstaak teenoor die heidene nie uitgevoer het nie, maar misbruik gemaak het van die predikantenood in S.A. om 'n nuwe kerk te stig, indien nie lasterlik nie dan wel ligsinnig. Ook teenoor Van der Watt 1977 se cordeel dat die ,afskeiding" nie kerkregtelik te verantwoord is nie, kan nou reeds gekonstateer word dat die stigting van die Gereformeerde kerk in S.A. 'n lewende prediking is dat die kerk geen menslike instelling is nie, maar die eiendom van God onder die Hoof Jesus Christus, wat hom by die instituering en regering daarvan bedien van mense.

\subsubsection{Die optrede van Postma voor die Stigting self.}

$\mathrm{Om} \mathrm{u}$ nie met te veel besonderhede te vermoei nie, verwys ek u net na die optrede van ds. Postma vanaf sy aankoms in Kaapstad, op sy reis na en sy aankoms in die Z.A.R. (Vgl. Journaal P/V ook afgedruk by Postma 1905). Dit getuig deurgaans van 'n lewendige bewustheid dat hy deur Jesus Christus geroep en gestuur is ten behoewe van sy kerk in die Z.A.R. Pynlik noukeurig verantwoord hy dan ook elke optrede aan sy senders. Hy hou hom aan sy opdrag terwyl hy ook die wettige kerkregeerders in S.A. vanaf die Kaap tot in Transvaal met alle agting sonder enige vooroordeel bejeën.

Wanneer die broeders wat hom in Natal gaan haal het, uit vrees dat hy hom sou erger, hom voorbereidend meedeel dat hy ooreenkomstig die grondwet van die Republiek deur die Algemeene Kerkvergadering ondersoek sou word na sy gereformeerdheid, erger hy hom nie, maar ,veeleer verblijdde het mij, dat ik deze belangstelling in een waar Gereformeerd leeraar zo ernstig vond ..." (Postma 1905. p. 93). Hy is die geroepe dienskneg wat aan alle geregtigheid wil voldoen. Waardig aan sy opdrag antwoord hy dat hy hom nog nie daaroor kan uitlaat of hom vir die bediening van die wat nie gesange sing nie beskikbaar sal stel nie. Hy moet eers gaan vasstel wat die behoeftes is.

Fors en tog nederig tree hy ook na vore as die gesant van Christus wat sy Sender meer gehoorsaam is as die mense wanneer hy op 11 Januarie 1859 skryf: „Het doet mij leed, dat ik mij volgens Gods Woord, niet gerechtigd acht, om u Eerw. als Algemeene Kerkvergadering, onder uw genomen besluit, met het oog op de geopenbaarde gevoelens, de hulp onzer kerk toe te zeggen" (Postma 1905, p. 122). Daarna hou hy hom afsydig as die vyftien beswaardes die vergadering verlaat, totdat hulle hom om hulp nader (vgl. Journaal $\mathrm{P} / \mathrm{V}$ onder datum 11 Jan. 1859). As hulle hom dan nader willig hy eers in om hulle te help nadat hy aan hulle voorgehou het ,dat daar voor hen strijd en moeite zouden verbonden zijn" (Geschiedenis sedert 1858, p. 10). "Nu zag en gevoelde ik mijne roeping, sprak en bad met hen. Op het verzoek, schreef ik uit hunnen mond hunne verklaring voor hen op ..." (Journaal P/V). Geen forsering of aanhitsing van 'n afskeiding nie! Veeleer 'n biddende tasting na die weg wat die Here voorskryf . . . !

Selfs op die stadium gryp ds. Postma nie vooruit op die gebeure nie. Die 15 man het hom hom gevra om 'n vergadering te Rustenburg te lei op 10 Februarie 1859 om alles nader te reël en die „Weleer- 
waarde Heer Postma beloofde zich dan nader te zúllen verklaren". Van toe af het hy alles begin gereed maak vir die vergadering o.a. deur 'n kerkorde op te stel (Rustenburg 1/2).

Op 21 Januárie 1859 gee hy kennis aan ds. D. van der Hoff van die stand van sake dat ,Verzocht van hen, die in dit land als een vrije Gereformeerde Kerk wenschen te bestaan, om hun mijne hulp te verleenen, gevoel ik mij verplicht $U$ eerwaarde te melden, dat die Broeders besloten hebben om den 10 den Februarie e.k., zoo de Here wil, te Rustenburg, eene kerkelijke samenkomst te houden „ter regeling hunner kerkelijke belangen ... " (Journaal P/V ook by Postma 1905 , p. 126).

Op. 24 Januarie 1859 het ds. D. Postma te Rustenburg besoek ontvang van ds. D. v.d. Hoff. In hulle gesprek ,over Gods Koninkryk in 't gemeen", het ds. Postma die skoonste geleentheid ontvang ,om oor die ware aard van Gols Koninkryk bloot te leggen, ook in welke betrekking wij dat moeten beschouwen tot de overheid". Hy voer aan dat die koninkryk van God, die kerk, geheel en al 'n geestelike liggaam is wat ,,in geenen deele afhanklijk moet zijn in zijn werking en ontwikkeling van een fiat van de overheid, hoewel zij anders den kerk mag ondersteunen". (Journaal P/V inskrywing onder 14 Jan. 1859).

Hierdie opvatting oor die verhouding kerk en owerheid hoewel hy hom aanvanklik gedra het in onderworpenheid aan die owerheidsbepalinge vir die kerk, het hy reeds op 11 Januarie 1859 in sy brief aan die Algemeene Kerkvergadering sterker dog beleefd gestel in sy kennisgewing dat hy voortaan alleen sal handel ,als wettig geordend en gezonden dienaar des Heeren . . . overeenkomstig de kracht mijner goddelijke zending" (by Postma 1905, p. 122).

$\mathrm{Na}$ die stigting van die Gereformeerde Kerk lê die ,Eerste Algemeene Kerkelijke samen komst van de Gereformeerde Kerk in deze lande" aan die owerheid 'n Kẹrkorde voor ",ter informatie" en spreek voorts die hoop uit dat die Geref. Kerk die nodige beskerming sal geniet (Postma 1905, p. 143). Hierdie opvatting word in die stryd om erkenning deur die owérheid, konsekwent gehandhaaf. En wanneer die owerheid volhard om net die Hervormde Kerk te erken, neem die Algemeene Vergadering van die Z.A.R. op 27 September 1861 die ferm besluit: „Voorts als Gereformeerde Kerk in de ware Christelijke Vrijheid voort te wandelen met de hulp en de genade des Heeren, onaangezien hoe ook de overheid met ons handelt" (art. 4, Zesde Algemeene Vergadering te Rustenburg, den 27 Sept. 1861).

Voor die samekoms op 10 Februarie het baie Rustenburgers by ds. Postma aangedring om by hulle te bly as herder en leraar. Aan hulle het hy gesê: „Vrienden! Zet $u$ daarop nog niet zoo vast, want het zal nog eerst moeten beproefd worden" (Journaal, onder datum 31 Jan. 1859 P/V). Die bewering van C. v.d. Waal (1964): „In ZuidAfrika wordt Postma beroepen door de gemeente Rustenburg. Wanneer de Synode van de Nederduitsch Hervormde Kerk de verpligting oplegt om in elke dienst een gezang te laten zingen, weigert Postma en ziet zijn taak beëindigd" (p.92) is seker nie histories verantwoord nie. Wat wel waar is, is dat Postma blykens sy eie verhaal in die Journaal, deur sowel die versoek van die 15 man te Pretoria as dié van die Rustenburgers op 'n buitengewone wyse beroep is - nie deur 
die Hervormde Kerk nie, maar wel deur dié wat onder sy leiding nog tot 'n Gereformeerde Kerk geïnstitueer wou word. Hy gryp egter nog nie vooruit op die konstituering nie. Hy erken die „beroep" onder buitengewone omstandighede, maar gaan voort om sy roeping kragtens sy sending te volbring.

\section{Die optrede van Postma tydens die Stigting}

Op 10 Februarie 1859 teken hy aan: „De dag der bestemde zamenkomst is aangebroken! Deze nacht heb ik zeer weinig geslapen, sta vroeg op, mocht ernstig bidden ..." (Journaal P/V). Van 8-12 is ,kerkelijke zaken" aan die Broeders voorgelees ter voorbereiding van die konstituering van die Gereformeerde Kerk. 'n Tent is onder seringbome op 'n aangebode erf opgeslaan, waarin ,,ouden van dagen” kon sit en ds. Postma sy papiere op 'n tafeltjie kon plaas. Nadat hy die ,,menigte" toegespreek en. ook aan hulle 'n „Gewijzigde Kerkorde" voorgelees het, het hy hulle ,voor al de zwarigheden" gestel „die zij als zij nu vrijmoedig voor hun geloof uit kwamen, al zouden te duchten hebben, en deed hun vele gemoedelijke vragen, hen beproevende . . . zeggende tot hen: als ze niet bereid waren . . . achter den Heere te komen, ... dat ze dan liever moest achterblijven, en zich niet bij de Gemeente voegen ... " Die aand ,voegen zich tot de Gemeente meer dan driehonderd lidmaten. Op 10 Februarie 1859 den dag der stichting... worden de volgende personen als lid. maten in geschreven ...." (Journaal, 10 Febr. P/V).

Die oggend van die 11de het die „menigte" weer byeengekom en ds. Postma het 2 Kor. 4 voorgelees, daarna die seëngroet gegee en weer uit Romeine $1: 8-17$ gelees en toe na enkele woorde voortgegaan: „En - dat nog veel meer zegt: Dat ik mij heden plechtig verklaar de bediening van Herder en Leraar onder $u$ op te nemen, in. den naam en kracht des Heeren". Na verdere gevoelvolle woorde het hy 'n gebed gedoen, Ps. $68: 14$ laat sing, waarna die gemeente nog staande Ps. 134:3 gesing het voor die seën uitgespreek is. Eers daarna is ouderlinge en diakens gekies.

Dit moes aangrypend gewees het - hierdie instituering van die kerk van die Here onder buitengewone omstandighede! Hoewel daar volgens die letter van die wet baie op die handelswyse aangemerk kon word, is die instituering desondanks tog suiwer skriftuurlik en kerkordelik. Volgens die grondbeginsels van die skriftuurlike kerkreg is op grootse wyse onder leiding van die Heilige Gees gehandel vanaf die eerste optredes in S.A. en in Nederland.

Op wettige wyse gestuur het ds. Postma die roeping aanvaar onder die besef dat die kerk die eiendom van Christus is en dat Hy alleen sy kerk regeer, hoewel deur die diens van mense. Hulle mag egter sy kerk net ooreenkomstig sy Woord institueer en regeer. As getroue dienskneg vervul ds. Postma sy roeping onder die gedu. rige versugting: „O Heere, schenk mij toch uwe liefde en genade, hulp en bijstand!... O Heere, versterk in mij de zelf verloochening!" (Journaal $P / V$ ). Hierdie versugting word al in die herhaalde uitroepe „O !" en „Och dat wij” . . . in sy briewe en afskeidsredes voor sy vertrek in Nederland gehoor. Ootmoed beheers sy hele optrede. 


\section{Die basiese beginsel in Kerkorde}

In die „Voorberigt” van die Kerkorde wat op 10 Februarie 1859 aan. vaar is (Rustenburg 1/2), stel ds. Postma sy eie kerkregtelike opvattinge baie duidelik. Die K.O. is noodsaaklik en daarin moet die goddelike en menslike altyd onderskei word. Wanneer die opsieners hierdie onderskeiding nie maak nie, kan dit so lig 'n ,vervolging tegen de vromen te weeg brengen, ofschoon zij naar 's Heeren Woord leven". Die Kerkorde moet altyd aan die Skrif en belydenis getoets word sodat daar in die kerkregering altyd na waarheid gehandel kan word „en men nimmer de gewoonte boven de waarheid Gods achte". In die kerkregering moet ook altyd gebid word om die „Heiligen Geest tot onze verlichting, heiliging en leiding" (Rustenburg 1/2).

Vir ds. Postma en die gereformeerdes is die Kerkorde, in teenstelling met die wette en reglemente waaronder hulle tot 1859 kerklik moes leef, nie wetties-dwingend nie, wel geestelik oorredend en leidend, nogtans gesagvol. Die kerkreg kon dan alleen beoefen word deur manne vol van die Heilige Gees en daarom vol van Wysheid (vgl. Handelinge $6: 3$ ).

\subsubsection{Die periode van verdere kerkregtelike ontwikkeling.}

Die kerkregtelike ontwikkeling sedert 1859 lewer 'n boeiende verhaal. Sommige acta is feitlik een groot kerkregtelike verhandeling. Ek kan ongelukkig nou net kursories op hoofmomente van die ontwikkeling die aandag vestig.

\section{Nog die genootskaplike kerkbegrip}

Ek konstateer veral dat die ontwikkeling, ten spyte van die suiwere Skriftuurlike uitgangspunte wat die stigting van die Gereformeerde Kerk te Rustenburg beheers het, tog bemoelik is deur 'n kerkbegrip wat - in soverre dit die instituut betref - onduidelik gebly het. Onder leiding van ds. Postma is, wanneer die instituut ter sprake kom, aangesluit by die heersende spraakgebruik. Daar is nie losgebreek van die genootskapsbegrip nie. Daar word steeds gepraat van die kerk wat uit gemeentes bestaan. Ds. Postma skryf bv. aan die kerkraad van Reddersburg: „En hoewel ik niet lidmaat ben van deze plaatselijke gemeente, maar wel van de Geref. Kerk en wel een leraar in dezelve ...." (Dokument 402, $\mathrm{P} / \mathrm{V}$ bls. 342).

In die "Kort Voorberigt" van die K.O. skryf hy ook "dat de kerk zelve het regt heeft zulk eene kerkorde steeds naar de omstandigheden, in welke de kerk verkeert, te wijzigen en te veranderen. Namelijk de opzieners der Kerk, Algemeen vergaderd om over de belangen der kerk te raadplegen, hebben daartoe regt..." 'n Meerdere vergadering is dus ' $n$ vergadering van opsieners van die algemene kerk in die land - die kerkraadsvergadering van die landskerk. Op die eerste Algemeene Vergaderings in die Z.A.R. is dan ook suiwer plaaslike sake van Rustenburg, Mooirivier en Pretoria, behandel, op so 'n wyse dat dit duidelik is dat die ,groter kerkraad" besig is met die sake van die landskerk.

So is in art. 10 van die ,Tweede Algemeene Kerkvergadering van die Gereformeerde Kerk in de Z.A. Republiek" besluit dat ,al die 
inkomende Kerkegelden, behalwe die bepaald gegeven worden voor Kerk en Pastorie te Rustenburg, in één kas zullen zamen plonzen en zijn voor de Algemeene Kerkelijke belangen ...." Op die derde Algemeente Vergadering word sensura-morum gehou met die oog op die nagmaalsviering (art. 2) en 'n voorsinger benoem (art. 3) (Rustenburg 1/1) (vgl. vir dieselfde opvatting (J. Bannerman 1869, herdruk 1974).

D'e gevolg van hierdie opvattinge, gestimuleer deur die omstandigheid dat ds. Postma vir 'n lang tyd die enigste predikant was wat die kerke moes bedien, was dan dat die kerkrade dikwels al te maklik sake na meerdere vergaderings verwys het. Hoewel daar tot min of meer in die veertiger jare van hierdie eeu deeglik rapport van die handelinge van meerdere vergaderings op gemeentevergaderings gegee is, het daar tog ' $n$ altyd weier kloof tussen die gelowiges en die meerdere vergaderings gekom. Die meerdere vergaderings is as "hogere" vergaderings beskou wat belas is met die kerkregering. Die Algemeene Vergadering van Transvaal gaan in 1872 sover om die gewese ds. N. J. R. Swart, wie se bedanking reeds deur die kerkraad aanvaar is, af te sit en as lidmaat te sensureer (Prof J. P. Jooste 1958 p. 127).

\section{Intuitiewe Gereformeerde aanvoeling}

Die vaders het ten spyte daarvan dat met die verkeerde kerkbegrip geopereer is, tog so 'n fyn-aanvoeling - vanweë hulle gereformeerde voelhoring vir die Skriftuurlike kerkreg gehad dat daar nie weer terug geval is in die hiërargie wat ontvlug is nie. Op die Sinode te Rustenburg 1863 het hulle die Kerkorde, deur ds. Postma opgestel en wat deur die genootskapsbegrip beheers is, tersyde gestel vir die D.K.O., gewysigd na omstandighede. „In de kerkregering, zal zij zich, zoo veel de omstandigheden van het land . . . toelaten gedragen naar de Kerkorde, vastgesteld in de bovengenoemde Synode te Dordrecht ...." (Art. 12). Hoewel die sinodale agenda dikwels met suiwer plaaslike aangeleenthede oorlaai is, het die vergadering in baie gevalle tog gewaak teen die versoeking om plaaslike sake, soos die verhuur van sitplekke, te reël (vgl. o.a. art. 37, Acta 1863).

Vanaf ongeveer $1903 \mathrm{kom}$ daar 'n kentering. Die invloed van die Doleansie, aanvanklik veral deur die optrede van dr. J. D. du Toit wat geskool is in die Doleansie-kerkreg, het begin deurwerk. Die beginsel dat die plaaslike kerk volkome kerk is en dat die kerke of gemeentes tesaam nie 'n ,groter kerk" vorm nie, is aangegryp. Die selfstandigheid van die plaaslike kerk is bewustelik op die voorgrond gestel terwyl die kerkverband beleef is - soos dr. A. Kuyper (1884) dit gestel het - as 'n vrywillige „foederatie" van plaaslike kerke (vgl. p. 7 en 32 e.v.). Rutgers (1882) stel dit so: Die eenheid van „kerkelijke vormen is dan wel wenschelijk, maar het kan tog ook wel als die ontbreekt" (p. 55).

\section{'n Spanningsituasie tussen kerkreg en kerkbegrip}

Hierdie ontwikkeling laat 'n spanning merkbaar word in die beoefening van die kerkreg in die Gereformeerde Kerk in S.A. Ener- 
syds werk die Postma-kerkbegrip nog deur en andersyds dring die opvatting dat die plaaslike kerk volkome kerk en daarom outonoom is, na vore. Dit het op sy beurt weer die independentistiese spook om die hoek laat loer.

Hierdie spanning het veral opgelaai rondom sake soos die naam van die kerk. Reddersburg O.V.S. (1927) het besluit ,volgens Art. 42 Sinode 1869 , en die openbare verklaring deur dieselfde Sinode opgestel, is die offisiële naam, van die verskillende Gereformeerde Gemeentes in S A., wat in één kerkverband staan, „De Gereformeerde Kerk in Zuid-Afrika'. Op advies van 'n kommissie word die naam egter in Afrikaans vertaal (art. 153 en bylaag U, p. 169). Opval lend het ds. A. S. E. Yssel en sy kerkraad nie met die besluit saam gestem nie en die korresponderende kerkraad gee die „Handelinge van die Twee- en twintigste Sinodale Vergadering van die Gereformeerde Kerke in Suid-Afrika, in sitting byeen op Reddersburg. O.V.S., ... " uit. Rustig word gehandel soos in 1924 asof die beskrywingspunt om die naam te verander na „Die Geref. Kerke van S.A." (art. 24) wel aanvaar is, terwyl dit nie so is nie ! Voor 1924 is gespreek van die „Handelinge van Gereformeerde Gemeenten”, terwyl daarmee bedoel is "De Gereformeerde Kerk in Zuid-Afrika".

Probleme duik ook vanweë die kerkbegrip op oor sake soos die sending (vgl. Handelinge 1924 en 1927, asook P. J. S. de Klerk 1923); diakonale inrigtings en deputaatskappe (Handelinge 1949); vaste sekretarisse vir deputate groepe (1949) en katkisasie organiseerder (1955 en 1958). Herdie is maar 'n paar sake wat willekeurig uitgelig is. Die acta vanaf die laat sestiger jare tot vandag toe toon egter dat daar op altyd indringender wyse geworstel word met die invloed wat die kerkbegrip op die kerkreg het.

Die worsteling is vir ' $n$ groot deel ook nog te wyte aan die aanvanklike, byne klakkelose, navolging van die Gereformeerde Kerken in Nederland. Hoewel dr. A. Kuyper (1884), Rutgers en Lohman (1886 en 1887) die beginsel dat die plaaslike kerk as selfstandige openbaring van die liggaam van Christus nie die verpligting tot die organisasie van die kerke wat een is in belydenis ophef nie, duidelik gestel het, het hulle tog versuim om die toepassing van die beginsel in die kerkregering behoorlik uit te werk. Dit het meegebring dat die beginsel self in menige polemiese geskrif (vgl. o.a. Rutgers 1882; van Lonkhuyzen 1926 en in later jare dr. S. Greidanus plus minus 1944) en selfs in die groot werk van Bouwman (1928 en 1934) oor die kerkreg, verduister is deur eensydighede. Dit het weer reaksie uitgelok met gevolglike ander eensydighede.

Waar daar altyd vanuit S.A. swaar geleun is op die kerkregtelike beskouinge vanuit die Gereformeerde Kerken in Nederland, is dit te begrype dat die eensydighede rondom die kerkbegrip by ons nie juis afgeneem het gedurende die eerste helfte van die 20e eeu nie.

In Nederland het die spanning uitgeloop op die skeuring in 1944, waarin die wrange vrugte van die eensydighede blootgelê is. By die sogenaamde sino? ales is meer en meer oorgeskakel na die sinodokrasie, soos blyk uit die H.K.O. van die vyftiger jare. Dit is tans so erg dat die sinode vandag feitlik omskep is in 'n soort permanente kerklike parlement wat gedurig in sitting is. 
Die sogenaamde Vrygemaaktes het andersyds ellendes teëgekom deur die oorbeklemtoning van die plaaslike kerk. So erg, dat hulle weer geskeur het (vgl. J. Kamphuis 1967).

Genadiglik is hierdie vrugte van die spanning op kerkregtelike gebied ons nog gespaar. Dit is, menslikgesproke, grotendeels te danke aan die feit dat in ons worsteling om die Afskeiding en Doleansie met mekaar te versoen, ons ongemerk na kerkregtelike selfstandigheid beweeg het. Van hierdie selfstandigheid het ons eensklaps bewus geraak terwyl ons besig was met die hersiening van die kerkorde. Aanvanklik (1955 en 1958) en selfs 1961, is nog geneig na 'n slaafse navolging van die Nederlanders se hersiening. Die sinode van 1961 besluit egter om op prinsipiële gronde 'n eie weg te gaan, met die gevolg dat in 1964 'n hersiene K.O. goedgekeur is wat totaal van die Nederlandse verskil. Die D.K.O. is in wese behou. Die Geref. Kerk in S.A. het kerkregtelik selfstandig geword. Daar word, sonder om die geskiedenis te minag, in die beoefening van die kerkreg weereens teruggegryp na Skrif en Belydenis.

\section{4. 'n Toekomsblik}

4.1. Die eerste eeu van kerkregsbeoefening in die Gereformeerde Kerk in S.A. het as vrug 'n eie kerkreg met gevolglik 'n eie kerkregering wat in die tweede eeu verder uitgebou moet word.

Daarmee is die Geref. Kerk in S.A. nie op 'n rewolusionêre weg besig om met sy eie geskiedenis en die van die kerk van Christus deur die eeue, te breek nie. Inteendeel, daar word juis na die geskiedenis - ook van die Afskeiding 1834 en die Doleansie 1886 sowel as die vereniging van 1892 - teruggegryp. Dit is egter nie meer die slaafse navolging wat die sogenaamde „,dogterkerk" aan ,die moederkerk" verskuldig is nie. Daar is gekom tot die selfstandige beoefening van die Gereformeerde Kerkreg, wat inhou 'n eie ontwikkeling met die Heilige Skrif en die Belydenis as die primêre bronne (vgl. J. J. v.d. Walt 1976, p. 15) en met die geskiedenis waardeur die leiding van die Heilige Gees in die kerk van alle tye erken word - as die sekondêre bron, waaruit geput word (vgl. Rutgers 1882 , p. 7).

\subsection{Die Kerkreg en die Wese van die Kerk}

Omdat die kerkreg en daarmee die kerkregering ook tot die wese van die kerk behoort, is die beoefening daarvan van deurslaggewende betekenis vir die toekoms van die Gereformeerde kerk in S.A.

Hierdie stelling is kontra die tradisionele opvattinge van die Gereformeerde canonici. Die Handleiding (1966) het hierdie Gereformeerde konsensus só geformuleer: „'n Kerkorde is nie vir die wese van die kerk nie, maar wel vir die welwese noodsaaklik". (p. 43). Met ander woorde die kerkorde as neerslag van dit waarmee kerkreg as teologiese wetenskap hom besig hou, is nie nodig vir die bestaan van die kerk nie, maar net vir die „goeie en ordelike bestaan" daarvan; dit ,dien dus ... . sodat die kerk beter aan sy roeping kan beantwoord, terwyl heersug en willekeur voorkom word" (p. 43). Die kerk kan dus sonder die reg, soos vergestalt in die kerkorde, 
bestaan; nog kerk wees. Ds. M. R. v.d. Berg (1969) ontken selfs die noodsaak van kerkorganisasie en so van 'n kerkreg en kerkorde, vir die welwese van die kerk (p. 56).

Om my stelling en die kontrastelling teen mekaar op te weeg moet die aandag eers weer gevestig word op die vraag wat kerkreg is. H. Bouwman (1928) sê: Kerkreg is die wetenskap ,die beschrijft het recht, dat in de zichtbaar geïnstitueerde kerk geldt en gelden moet" (p. 10). Die kerkreg speur dus die beginsels na vir en pas dit toe in die kerkregering. In enger sin is die kerkreg dan "die reëls wat deur die ampsdraers uit die beginsels, gegee in die Woord van God, gevorm is vir die gedrag in die gemeenskap van die gelowiges" (v.d. Linde 1965, p. 32).

Die vraag waarom dit tans in ons ondersoek gaan is of kerkreg in hierdie sin van wesenlike belang vir die kerk is - met ander woorde of dit saamval met die bestaan van die kerk; of die kerk sonder hierdie reg nog kerk is, of kan wees en of dit maar iets is wat by die periferie van die kerk tuishoort? Is die beoefening van die kerkreg net van belang vir 'n beter-kerkwees van die kerk, maar nie vir die kerkwees self nie?

My stelling antwoord: sonder kerkreg (en dus kerkorde) kan daar geen kerk wees nie !

Hierdie stelling word eerstens gedra deur die Belydenis. Artikel XXIX spreek van die „merktekens om die ware kerk te onderskei” - dus van die wesenstrekke, waaruit vasgestel kan word of dit wat voorgee om kerk te wees, inderdaad kerk is. Die wesens, trekke (merktekens) is: die suiwere prediking van die evangelie, die suiwer bediening van die sakramente en die kerklike tug. Hierdie merktekens moet aanwesig wees in die geïntitueerde kerk voordat dit as kerk erken kan word. Dit is gegee in die wese van die kerk as liggaam van Christus, wat die vergestalting van die koninkryk van die hemele is in so verre dit reeds gekom het op aarde (vgl. v.d. Linde 1976). Daarom vervolg die Belydenis: „Kort gesê, as almal hulle ooreenkomstig die suiwere Woord van God gedra alles verwerp wat daarteen stry en Jesus Christus erken as die enigste Hoof".

Die kerk word verder ook in die N.T. steeds voorgehou as die liggaam van Christus (o.a. 1 Kor. $12: 12$ e.v.), of as gebou met Christus as die hoeksteen of fondament (o.a. 1 Kor. $3: 10$ en 1 Petr. $2: 4$ ). Daarin kom uit dat die kerk die ,maaksel" van God is, geskape in Christus Jesus tot goeie werke wat God voorberei het, sodat ons daarin kan wandel (Ef. 2:10). Die N.T. hou die kerk voor as 'n konkrete, sigbare en aanwysbare instelling, deur die wondere werk van God in Christus Jesus te voorskyn geroep (vgl. H. Bavinck 1911, p. 322 e.v.). Met Christus is die kerk gegee. Sonder Hom is geen sprake van die kerk nie. Hy is die Hoof en die lede van die kerk is lede van sy liggaam; sonder die Hoof is daar geen liggaam nie. Hý is die hoeksteen of fondament; sonder Hom kan daar geen kerk gebou word of bestaan nie (vgl. W. van 't Spijker 1972, p. 13 e.v.).

Hierdie aanwysing van die kerk met Christus as Hoof, gryp terug na die kern van die N.Tiese prediking: „Bekeer julle; want die Koninkryk van die hemele het naby gekom". (Matt. 3:2). Hierdie prediking stel ons hele bestaan ondergeskik aan die soewe- 
reine God. Dit is die oproep tot, of aansegging van die mensheid om God as Koning te erken en om hulle aan Hom te onderwerp. Daarom kan dieselfde prediking net in 'n ander vorm as 'n laaste prediking aan die einde as die engel wat in die middel van die lug vlieg, met 'n groot stem sê: „Vrees God en gee Hom heerlikheid, want die uur van sy oordeel het gekom ..." (Openb. 14:7). Die tyd het - ook reeds tydens Johannes se optrede - aangebreek dat Hy sy koningskap só laat geld dat elkeen, ook teen wil en dank, sal moet erken: God is Koning! Die tyd is daar dat die werklikheid onafwendbaar op elkeen sal aandring; en as daar nie bekering is nie die smartkreet, gerig tot die berge en rotse sal laat opstyg: „. . . val op ons en verberg ons vir die aangesig van Hom wat op die troon sit ..." (Openb. 6:16). Dit sou die smartkreet van die hele mensheid wees, maar God laat sy eiendom ten spyte van die opstand teen Hom, nie vaar nie. Daarom dra Hy die realisering van sy Koninklike heerskappy op aan Jesus - aan Hom wat sy volk van hulle sondes sal verlos. Hy maak God se volk weer aan Hom gehoorsaam deur hulle met Homself en mekaar deur die geloof in Hom te verenig. Hy is hulle Hoof deur wie hulle regeer word. Die lede van sy liggaam vergader Hy as sy kerk - die burgers van die Koninkryk van die hemele word as eenheid - éen liggaam - saam verbind onder die heerskappy van die Koning. God het sy soewereiniteit in die kerk aan Christus oorgedra (Bavinck 1911, p. 355).

Die wese van die kerk word só gevind in die verhouding van die Koning en sy onderdane. Hy is soewerein; na sy woord moet geluister word en sy onderdane is volkome aan Hom onderworpe vgl. Markus 9:7. Vandaar dat die suiwere bediening van die Woord, waaraan dié van die sakramente gekoppel is en dié van die tug as wesenskenmerke van die kerk aangegee word (art. XXIX N.G.B.). Die kerk is alleen kerk as dit dié wesenskenmerke vertoon wat in hierdie verhouding opgesluit is, naamlik om as burgers te verenig op die wyse wat Christus beveel en onder sy heerskappy hulle te gedra volgens sy voorskrifte; sowel vir hulle as vergaderde burgers en burgers elkeen afsonderlik. Die kerk moet dus reg d.w.s. na die voorskrifte van Christus, geïnstitueer en in stand gehou word (vgl. Calvyn, p. 13). En die lede van die kerk moet hulle reg gedra. Hulle lewenswandel inrig volgens sy wet! Vgl. Ef. 1:22; 1 Kor. 14:40. Dié kerk kom so in die wêreld tot openbaring deur die belydenis: „Ek glo in Jesus Christus onse Here". Die soteriologie - die leer aangaande die mens se verlossing - kulmineer so in die Christokrasie. Die kerk ,als volk Gods", is 'n teokrasie en God het sy soewereiniteit, aan Christus oorgedra (Bavinck, 1911, p. 355). Die kerk is derhalwe wesenlik 'n regsgemeenskap; die nuwe mensheid wat die leuen van Satan verwerp vir die waarheid van God dat die aarde aan Hom behoort en die volheid daarvan, „die wêreld en die wat daarin woon . . ." (Ps. $24: 1$ ). Daar kan eers van Kerk sprake wees as daar onderwerping aan die Koning is, as Jesus Christus waarlik vir ons Here is! Bij de kerk als vergadering der geloovigen is eene regeering onmisbaar. Gelijk ... by het rijk een koning behoort, zoo is ook de kerk niet zonder een gezag te denken, dat haar draagt en leidt, verzorgt en beschermt" (Bavinck 1911, p. 355). 
Waar die kerk die vergadering van die burgers van die Koninkryk van die hemele is, het die kerkreg ook 'n kerugmatiese strekking. "In ihren eigenen Kirchenrecht spricht die Kirche sich von ihrem Wesen her im Blick auf ihre Aufgaben aus und bezeugt so als Christengemeinde der Bürgergemeinde, dasz sie, ohne dem weltlichen Recht die Gültigkeit abzu-sprechen, doch nicht ihn, sondern dem Recht Gottes untersteht. In Gottes recht setzt Gott sich irdisch durch und schafft die ihm gehorsame Welt. Dieses Recht wirdt verkündigt. Wo as verkündigt und anerkannt wird, da ist die Kirche" (Stoodt 1962, p. 130). In sy bestaan as ware regsgemeenskap en in die beoefening van die kerkreg staan die kerk profeties teenoor die wêreld. Dit verkondig aan die wêreld dat reg alleen bestaan in dit wat God in Christus voorskryf en die onderwerping daaraan (vgl. v.d. Linde 1969, p. 221/2).

Daar kan alleen sprake wees van Kerk waar die reg van Christus vir sy kerk geken en gehandhaaf word (vgl. Walaeus in Synopsis II p. 89 en 92). Vir die wese van die kerk as vergaderde burgers van die koninkryk van die hemele is dit noodsaaklik ,om te wandel waardig die roeping waarmee julle geroep is ..." (Ef. 4:1). Eers in hierdie wandel - dit is in onderworpenheid aan Christus, die Hoof en Koning - word die Koninkryk van die hemele, in soverre dit reeds gekom het, aanskou in die kerk en is die kerk die heenwysing na die volheid van die koninkryk op die nuwe aarde. Die Koninkryk waarin die soewereiniteit van die Koning allesoorheersend is. „In diesem sinne ist die Kirche das Gottes Recht unterstellte Volk Gottes. In Ihr gibt Gottes Recht" (Dieter Stoodt. 1962, p. 129).

Die kerk se bestaan is so verweefd met die kerkreg. Alleen as dit geïnstitueer, ingerig en geregeer word na die reëls of wette wat Christus daarvoor gegee het, ontstaan en bestaan dit voort as kerk. Die reg kom nie eers later by sodat dit beter kerk kan wees en beter aan sy roeping kan beantwoord nie. „Das heisst einmal, dass Gottes Wort in ihr immer wieder Gottes Herrschaft aufrichtet und dass die versammelte Gemeinde im Heiligen Geist diese Herrschaft immer wieder anerkennt" (Stoodt, 1962, p. 129). Ook Karl Barth (1955) sê dat die „Ordnung" van die kerk wesensnoodsaaklik is en dat dit omskrywe kan word as wesensnoodsaaklik vir die opbouing van die kerk en as sodanig vir die communio sanctorum (p. 5) (vgl. ook Walaeus, Synopsis II p. 89). Bavink (1911) verklaar „Het is niet juist te zeggen, dat die wijze van inrichting en de vorm van regeering voor de kerk van Christus eene onverschillige zaak is. Zo los en onverschillig staan wezen en vorm... nooit naast of tegenover elkaar" (p. 403).

Selfs M. R. van den Berg (1969) wat so beslis verklaar dat kerkorganisasie nie tot die wese van die kerk hoort nie, kon nie anders as om weer na organisasie en daarmee die kerkreg terug te gryp nie. Hy soek direkte N.Tiese riglyne byeen „voor het leven van Christus gemeente" (p. 92). Die ironie is dat die "grondregels" wat hy eindelik ontdek waarvolgens die "gekerkerde kerk" na sy verlossing gestuur moet word, maar basies dié is wat in die D.K.O. neergelê is. Ook hy soek direkte riglyne uit die N.T. byeen ,,voor het leven van Christus gemeenten ... Deze richtlijnen kunnen dan dienen 
als een oriëntatiepunt by het nadenken over de koers die gevaren moet worden" (p. 92). So kry mens sig "op de structuur van de gemeente en het samenleven van gemeenten volgens het Nieuwe Testament".

Hoe versigtig Van den Berg ook al sy terme kies, kom hy tog maar uit by die feit dat die kerk wel volgens die N.T. 'n organisasie het en dat daar definitiewe voorskrifte vir die organisasie is; voorskrifte wat voortvloei uit die wese van die kerk. Hy vind dan 'n nege? en twintigtal ,grondregels" waarvolgens die kerk geinstitueer moet word.

Die kerk wat nog 'n toekoms wil hê moet terug na die N.T. gestalte (p. 85), ontdaan van die massaliteit moet dit selvormig georganiseer word sodat die lewende Christene as getuies van Christus in die wêreld kan verkeer (p. 85).

Die organisasie is nodig want die gemeente moet aan Christus onderdanig wees omdat Christus die Hoof is van die gemeente (p. 93). Dit is die eerste ,grondregel". Die plaaslike kerk is 'n eenheid as liggaam van Christus. „Deze eenheid van de plaatselijke gemeente behoort bewaart te worden" (reël 2). Daar is twee ampte (reël 4). Die Woord moet verkondig word (8). Die gemeente moet gereeld saamkom vir die diens van die Woord, gebede en sakramente (reël 14). In die samekomste moet alles ordelik toegaan (15). Teen valse leringe moet gewaak word 16).

Ek meen dat hiermee genoegsaam aangedui is dat ons hier maar weer met kerkorganisasie in die ou bekende sin van die woord te doen kry, asook met 'n konsep kerkorde wat, indien behoorlik geformuleer en gesistematiseer, ons basies weer by die D.K.O. sal tuisbring. Ten spyte van sy aanvanklike kategoriese afwysing van 'n „,met bindend gezag opgelegde kerkelijke organisatie" (p. 69) verklaar hy nadat die reëls nagespeur is, rustig: „In de hierboven gegeven regels is m.i. samengevat wat het Nieuw Testament direct over structuur en organisatie van de gemeente van Christus zegt". Dan rond hy sy algehele ommeswaai af wanneer hy wil kom tot 'n skriftuurlike vorm van kerklike samelewe; „een vorm waarin het evangelisch karakter van Christus' gemeente op de voorgrond staat en de mondigheid der gelowigen ten volle gehonoreerd kan worden" (p. 98). Dit gaan ten slotte dan tog nie vir hom om met alle organisasie en elke K.O. weg te doen soos hy op pp. 56, 68 en 69 eis nie, maar - so moet mens aflei - om 'n skriftuurlike organisasie wat pas by die wese van die kerk.

Ook die geskiedenis van die kerk het van die begin af uitgewys dat die kerkreg by die wese van die kerk hoort. Waar dit veral gedurende die derde eeu kerkregtelik skeef begin loop het, het die vervalsing van die kerk na dieselfde mate posgevat. En toe Luther in sy stryd om 'n genadige God te vind Hom in Christus gevind het, het hy meteens die kerndwaling waardeur die kerk vervals is, blootgelê naamlik dat die Pous Christus as hoof van die kerk verdring het. Dit kom veral uit in sy lesings gedurende $1510-1517$ (vgl. Wolfgang Stein, 1974 en M. Bahmann, 1967). Na die Reformasie in die sestiende eeu tot vandag toe het die vervalsing van die kerk telkemale ingetree waar die koningsreg van Christus deur menslike 
reg verdring word. Dit is tewens opmerklik dat by elkeen vir wie die kerkreg ' $n$ onverskillige saak is; en veral vir hulle wat vandag saam praat in die spreekkoor dat die ,gekerkerde kerk" verstrengel is in die bande en toue van die kerkreg, steeds terugval op hulle eie regsopvattinge.

Indien die Gereformeerde kerk in S.A. 'n toekoms van roepingstrou tegemoet wil gaan in die "swaar tye", waarin dit, ook in kerklike kringe, mode geword het om die wêreld na die mond te praat, moet ons daarop ag gee dat die kerkreg by die wese van die kerk hoort.

Juis die feit dat 'n valse kerkreg kerkontbindend werk lê die sware verpligting op ons om alle aandag aan die kerkreg te gee sodat ook in die kerkregering die burgers van die Koninkryk van die hemele in totale onderwerping aan die Koning van die kerk gehou word. Alleen dan kan die Gereformeerde Kerk in S.A. waarlik kerk bly.

\section{G. P. L. van der Linde}

Lesing gehou op die Aktualiteitskursus, Potchefstroom.

25 Julie 1978.

\section{VERWYSINGS}

1 Ds. M. R. van den Berg: 1969. De gekerkerde kerk. Buijten en Schipperheijn, Amsterdam.

2 J. Plomp: 1967. Beginselen van Reformatorisch Kerkrecht. Kampen Ca. hiers. Kampen.

3 Rudolp Sohm: 1962. Kirchenrecht, erster Band. Leipzig.

4 Erik Wolf: 1961. Ordnung der Kirche Frankfurt am Main.

5 In die Skriflig, 1976, Jaargang 10, Nommer 37.

6 In die Skriflig, 1977. Jaargang 11. nommer 43.

7 B. J. Odendaal, 1957. Die Kerklike Betrekkinge tussen Suid-Afrika en Nederland. Franeker.

8 S. P. Engelbrecht, (1953). Geskiedenis van die Nederduitsch Hervormde Kerk van Afrika. Derde Hersiene en Vermeerderde uitgawe. Kaapstad Pretoria.

9 Dieter Stoodt (1962). Wort und Recht. München.

10 G. P. L. van der Linde: 1969. Die Koninkryk van God en die kerkreg: in „Die Koninkryk van God." Potchefstroom.

11 Karl Barth: 1955, Die Ordnung der Gemeinde. München.

12 P. B. v.d. Watt: 1977. Die Nederduitse Gereformeerde Kerk 1934-1866. Pretoria.

13 Olof Linton: 1932. Das Problem der Urkirche in der Neueren Forschung. Uppsala.

14 U'rich Brockhaus: 1972. Charisma und Amt. Wuppertal.

15 B. R. Krüger: 1957. Die Ontstaan van die Gereformeerde Kerk in SuidAfrika. Pretoria.

16 G. C. P. v.d. Vyver: 1958. Dirk Postma. Potchefstroom.

17 B. Spoelstra: 1963. Die Doppers in Suid-Afrika 1960-1899. Nasionale Boekhandel. 
18 Prof. Jan Lion Cachet: 1909. Gedenkboek, Potchefstroom.

19 D. Postma: 1905. De Geschiedenis van de stichting en ontwikkeling der Gereformeerde Kerk in Zuid-Afrika. Paarl.

20 Eeufees-Gedenkboek: Die Gereformeerde Kerk in Suid-Afrika 1859-1959. Potchefstroom.

21 D. Postma Jnr.: 1893. Eenige Nagelatene Leerreden van Wijlen Prof. D. Postma, in leven prof. in de Godgeleerdheid te Burgersdorp, Kaapkolonie, Kaapstad.

22 J. S. L. Venter en L. J. du Plessis 1878. De Geschiedenis der Gereformeerde Kerk in de Zuid Afrikaanse Republiek (Transvaal) sedert 1858. Alsmede De Verzameling van de bepalingen der Algemeene vergaderingen van de Gereformeerde Gemeenten in de Zuid-Afrikaanse Republiek (Transvaal. Vasgesteld in 1877). Kaapstad.

23 D. Postma. Journaal P/V Argief Geref. Kerk in S.A.

24 G. P. L. v.d. Linde: 1959. Die Gereformeerde Kerk in Suid-Afrika. In Gedenkboek, Klassis Germiston.

25 Dr. C. v.d. Waal: 1964. D. Postma en Helenius de Cock in Lucerna, 5e Jaargang no. 2. Julie 1964.

26 D. Postma: Kerkorde voor de Gereformeerde Kerk in de Zuid-Afrikaansche Republiek. Argief Geref. Kerk in Suid-Afrika Potchefstroom. Rustenburg-versameling $1 / 2$.

27 Notuleboek: Rustenburg 1/1. G.K.S.A.-Argief, Potchefstroom.

28 James Bannerman: 1869. The Church of Christ.

29 Prof. dr. J. P. Jooste: 1958. Die Geskiedenis van die Gereformeerde Kerk in Suid-Afrika 1859-1959.

30 Handelingen van de Tweede Algemeene Synodale Vergadering der Gereformeerde Kerk, van de Zuid-Afrikaansche Republiek, Den Oranje Vrijstaat, En De Kaapkolonie in Zuid-Afrika, Gehouden van den $1-3$ Juny 1863, te Rustenburg (Zuid-Afrikaanser Republiek. Kaapstad.

31 Dr. A. Kuyper: 1884. Tractaat van de Reformatie der Kerken. Amsterdam.

32 F. L. Rutgers 1882: Het Kerkverband der Nederlandsche Gereformeerde Kerken, gelyk dat gekend wordt uit de Handelingen van den Amsterdamsche Kerkeraad in den aanvang der 17e eeuw. Amsterdam.

33 Dr. J. van Lonkhuizen: 1926. Een Ernstige Fout. Chicago.

34 Dr. H. Bouwman, 1928: Gereformeerd Kerkrecht. Eerste deel. Kampen 1934: Tweede deel. Kampen.

35 J. Kamphuis, 1967. Verantwoording van een Keus Anno Domini 1967. Goes.

36 Dr. P. J. S. de Klerk: 1923. Kerk en Sending in Suid-Afrika Amsterdam.

37 A. F. de Savornin Lohman, en F. L. Rutgers: 1886 en 1887. De Rechtsbevoegdheid onzer plaatselijke kerken. Utrecht.

38 S. Greydanus, s.j.: Schriftbeginselen van Kerkrecht inzake meerder vergaderingen. Enschede.

39 J. J. v.d. Walt, Th.D. 1976. Christus as Hoof van die Kerk en die Presbiteriale Kerkregering. Potchefstroom.

40 G. P. L. v.d. Linde: 1965. Die Grondbeginsels van die Presbiteriale kerkregeringstelsel. Potchefstroom.

41 Dr. W. van 't Spijker: 1972. Goddelijk recht en kerkelijke orde by Martin Bucer. Apeldoornse studies no. 3. Kampen.

42 Dr. H. Bavinck, 1911. Gereformeerde Dogmatiek. Vierde Deel. Kampen.

43 G. P. L. v.d. Linde, 1976. Die betekenis van die verhouding tussen die 
Koninkryk van die hemele en die kerk vir die kerkreg. P.U. vir C.H.O.

44 Dieter Stoodt: 1962. Wort und Recht. München.

45 Johannes Calvyn: Institusie of onderwijzing in de christelijke Godsdienst. Uit het Latijn vertaald door dr. A. Zizoo. Boek IV. Delft.

46 Johannes Polijander, Andries Rivetus, Antonius Walaeus, Antonius Thysuis, 1624. Synopsis of Overzicht van de Zuiverste Theologie. Vertaal deur Dirk van Dijk, 1964. Enschede.

48 Wolfgang Stein, 1974. Das Kirchliche Amt bei Luther. Wiesbaden.

49 M. Bhamann, 1967. The Development of Luther's Principle of Ecclesiastical Authority (1512-1520) in the German Reformation. University Microfilms.

\section{INOUGURELE REDES}

Die PU vir CHO het gedurende 1976 'n hele reeks inougurele redes gepubliseer in die reeks ,Wetenskaplike Bydraes van die P.U. vir C.H.O., reeks H. Dit het eers onlangs onder ons aandag gekom:

Nr. 14 P. J. Coetzee: Uitverkiesing en Bekering.

Nr. 15 G. C. P. v.d. Vyver: God en Mens in die Kerkgeskiedskrywing.

Nr. 29 J. C. Coetzee: 'n pleidooi vir die vernuwing en die besondere Kanoniek - toegelig aan die hand van die evangelie van Johannes.

Nr.31 F. N. Lion Cachet: God/die Here het al hierdie woorde gespreek. Die betekenis van die ,Inleidingsformule' van die dekaloog vir die O.T. Besondere Kanoniek.

Nr. 33 P. W. Buys: Die botsing van Pligte as Etiese vraagstuk. 